\title{
IMPLEMENTASI PELAYANAN PUBLIK PADA PROGRAM SIDUKUN 3 IN 1 DALAM PENGURUSAN ADMINISTRASI KEPENDUDUKAN DI DKI JAKARTA
}

\section{IMPLEMENTATION OF PUBLIC SERVICES IN THE 3 IN 1 SIDUKUN PROGRAM IN MANAGING POPULATION ADMINISTRATION IN DKI JAKARTA}

\author{
Iqbal Aidar Idrus ${ }^{\mathbf{1}}$ Komang Jaka Ferdian ${ }^{2}$ \\ Universitas 17 Agustus 1945 Jakarta \\ idrusiqbal@yahoo.com
}

\begin{abstract}
This study answers the implementation of the SIDUKUN 3 In 1 program in the implementation of population administration services. The program was developed to implement Law No. 24 of 2013 concerning Population Administration (Adminduk). The research method used in this study is a qualitative descriptive study, which was carried out at the DKI Jakarta Population and Civil Registry Office which is integrated with hospitals and BPJS Health related to the quality of population administration services. The results of this study indicate that the DKI Jakarta government has been quite successful in carrying out population administration services, but is still lacking in socializing the program. So that there are still many people who do not know the program "SIDUKUN 3 in 1" in providing services for children born in the hospital, immediately get a Birth Certificate from the hospital, Baby Population Registration Number (NIK), updated family cards, birth certificates, child's identity card and BPJS Health for infants. With fast and free administration of services, in 201979 hospitals, 44 puskesmas and 5700 birth certificates have been printed by the Dukcapil Office.
\end{abstract} Keywords: Policy Implementation; Public Service; Population Administration.

\begin{abstract}
ABSTRAK
Penelitian ini menjawab implementasi program SIDUKUN 3 In 1 dalam pelaksanaan pelayanan administrasi kependudukan. Program tersebut dikembangkan untuk mengimplementasikan Undang-Undang No. 24 Tahun 2013 tentang Administrasi Kependudukan (Adminduk). Metode Penelitian yang digunakan dalam penelitian ini yaitu penelitian deskriptif kualitatif, yang dilakukan di Dinas Kependudukan dan Catatan Sipil DKI Jakarta yang saling terintegrasi dengan instansi rumah sakit dan BPJS Kesehatan terkait dengan kualitas pelayanan administrasi kependudukan. Hasil penelitian ini
\end{abstract}


menunjukan bahwa pemerintah DKI Jakarta cukup berhasil melaksanakan pelayanan administrasi kependudukan, akan tetapi masih kurang dalam mesosialisasikan program tersebut. Sehingga masih banyak masyarakat yang belum mengetahui program "SIDUKUN 3 in 1" dalam memberikan layanan bagi anak yang dilahirkan di rumah sakit, langsung mendapatkan Surat Keterangan Kelahiran dari rumah sakit, Nomor Induk Kependudukan (NIK) bayi, Kartu keluarga yang sudah update, akta kelahiran, kartu identitas anak dan BPJS Kesehatan untuk bayi. Dengan pengurusan pelayanan yang cepat dan tidak dipungut biaya, pada tahun 2019 sudah 79 rumah sakit, 44 puskesmas dan 5700 akte kelahiran yang sudah di cetak oleh Dinas Dukcapil.

Kata kunci: Implementasi Kebijakan; Pelayanan Publik; Administrasi Kependudukan.

\section{PENDAHULUAN}

Peran negara sebagai penyedia layanan publik kembali dirasakan perannya, ketika gerakan liberalisasi dan pasar bebas yang terlalu belebihan, yang telah terbukti gagal mewujudkan impian banyak orang bahwa urusan pelayanan publik akan jauh lebih efektif, efesien, responsf dan akuntabel apabila disediakan oleh pihak swasta. Memang diakui bahwa praktik manajemen yang digunakan oleh organisasi bisnis jauh lebih baik dibandingkan dengan organisasi publik (birokrasi) . Hal ini terjadi karena organisasi bisnis memang jauh lebih sensitif terhadap tuntutan para pelanggan mereka (Purwanto, 2009). Dengan lahirnya Program SIDUKUN 3 in 1 yang merupakan Sistem Intergrasi kependudukan dalam 3 instansi di satu loket untuk mempercepat pelayanan administrasi kependudukan. Program ini digagas oleh pemerintah DKI Jakarta melalui Dinas Kependudukan dan Catatan Sipil agar mampu memberikan pelayanan yang baik seperti pelayanan yang di berikan pihak swasta. Dalam hal organisasi publik yaitu memperhatikan masyarakat tanpa membedakan kelas di mana semua masyarakat mempunyai hak yang sama dalam pengurusan administrasi kependudukan.

Pengukuran kinerja pelayanan publik pada dasarnya digunakan sebagai penilaian atas keberhasilan atau kegagalan pelaksanaan kegiatan yang dilakukan oleh organisasi atau pihak pelaksana dalam hal ini adalah pemerintah DKI Jakarta. Program atau kebijakan harus sesuai dengan sasaran 
dan tujuan yang telah ditetapkan dalam rangka mewujudkan visi dan misi instansi pemerintah. Pengukuran kinerja mencangkup penetapan indikator kinerja dan penetapan pencapaian indikator kerja. Dengan kata lain, pengukuran kinerja adalah metode untuk menilai kemajuan/hasil yang telah dicapai untuk dibandingkan dengan tujuan yang telah ditetapkan (LANRI,1999).

Indikator kinerja yang dimaksud yaitu ukuran kualitatif dan kuantitatif yang menggambarkan tingkat pencapaian suatu sasaran atau tujuan yang telah ditetapkan dengan mempertimbangkan indikator masukan (input), keluaran (output), hasil (outcome), manfaat (benefit), dan dampak (impact). Untuk mengukur indikator penyususn kinerja bisa menggunakan Seithaml, Parasuraman, dan Berry (1990) dalam Mukarom \& Laksana, (2016) yaitu tangibles atau ketampakan fisik, reliability atau reliabilitas, responsiveness atau responsitas, assurance atau kepastiam dan empathy. Sedangkan dalam Dalam pemahaman Grindle (1980) tersirat makna bahwa untuk mengukur implementasi kebijakan harus memperhatikan variabel kebijakan, organisasi dan lingkungan. Perhatian itu perlu diarahkan karena melalui pemilihan kebijakan yang tepat maka masyarakat dapat berpartisipasi memberikan kontribusi yang optimal untuk mencapai tujuan yang diinginkan. Selanjutnya, ketika sudah ditemukan kebijakan yang terpilih diperlukan organisasi pelaksana. Karena di dalam organisasi ada kewenangan dan berbagai sumber daya yang mendukung pelaksanaan kebijakan. Sedangkan lingkungan kebijakan tergantung pada sifatnya yang positif atau negatif.

Jika lingkungan berpandangan positif terhadap suatu kebijakan, maka akan menghasilkan dukungan positif. Sehingga ingkungan akan berpengaruh terhadap kesuksesan implementasi kebijakan. Sebaliknya, jika lingkungan berpandangan negatif maka akan terjadi benturan sikap. Sehingga proses implementasi akan mengalami hambatan. Lebih daripada ketiga aspek tersebut, kepatuhan kelompok sasaran kebijakan merupakan hasil langsung dari implementasi kebijakan yang menentukan efeknya terhadap masyarakat. 
Dalam penelitian ini, pendekatan Grindle dianggap tepat karena kebijakan pembangunan infrastruktur di kawasan perbatasan yang bersifat top-down berada pada arena politik dan administrasi. Selain itu, pendekatan Mazmanian dan Sabatier juga di pandang tepat karena selain sifatnya yang top-down.

Grindle (1980:7) menegaskan bahwa implementasi kebijakan dipengaruhi oleh dua variabel besar, yang meliputi: isi kebijakan (content of policy) dan konteks implementasi (contect of implementation). Variabel isi kebijakan (content of Policy) meliputi :

1) Sejauh mana kepentingan kelompok sasaran/target groups termuat dalam isi kebijakan,

2) Jenis manfaat yang diterima oleh target group,

3) Sejauh mana perubahan yang diinginkan dari sebuah kebijakan,

4) Apakah letak sebuah program sudah tepat,

5) Apakah sebuah kebijakan telah menyebutkan implementasinya dengan rinci,

6) Apakah sebuah program di dukung oleh sumberdaya yang memadai,

Sedangkan variabel konteks implementasi (contect of implementation), meliputi:

1) Seberapa besar kekuasaan, kepentingan dan strategi yang dimiliki oleh para aktor yang terlibat dalam implementasi kebijakan,

2) Karakteristik institusi dan rezim yang sedang berkuasa,

3) Tingkat kepatuhan dan responsivitas kelompok sasaran,

Sehingga lewat implementasi pelayanan publik pada program SIDUKUN 3 in 1 pada pelayanan adminsitratif kependudukan guna untuk mempermudah administrasi kependudukan bagi ibu yang baru melahirkan. Program ini lahir dari instansi Dinas Dukcapil yang juga melibatkan instansi lainya yaitu rumah sakit dan BPJS Kesehatan. Inovasi pelayanan ini memangkas sulitnya pengurusan administrasi kependudukan bagi bayi. Saat bayi lahir dan dibawa pulang sudah mendapatkan Surat keterangan kelahiran dari rumah sakit, nomor induk kependudukan (NIK) bayi, kartu keluarga yang 
sudah diperbarui, akta kelahiran, kartu indentitas anak (KIA) serta BPJS Kesehatan untuk bayi dan semuanya di dapatkan secara cuma-cuma tanpa dipungut biaya. Program inovasi pelayanan publik "SIDUKUN 3 in 1" mendapatkan penghargaan sebagai pemenang Top 99 yang diberikan oleh Kementerian Pendayagunaan Aparatur Negara dan Reformasi Birokrasi (Kemen-PAN RB) Republik Indonesia. Namun kebijakan tersebut diperhadapkan pada beberapa persoalan. Pertama, belum semua rumah sakit di DKI Jakarta mampu menjalankan program "SIDUKUN 3 in 1". Kedua, komunikasi yang dibangun dalam melibatkan koordinasi tiga instansi dalam implementasi pelayanan administrasi.

\section{METODE PENELITIAN}

Penelitian ini menggunakan metode pendekatan deskriptif kualitatif. Penelitian kualitatif dijelaskan oleh (Creswell, 2009) yaitu penelitian yang bersifat mengeksplor dan memahami makna individu ataupun kelompok dalam permasalahan kehidupan sosial. Data-data yang digunakan dalam penelitian ini didapatkan dari dari informan terkaiat dengan instansi yang bersangkutan. Teknik pengumpulan data yang digunakan yaitu dokumentasi dan sumber-sumber tertulis dan wawancara. Studi dokumentasi dilakukan mengenai jumlah pembuatan akta kelahiran tiap tahunya, rumah sakit yang sudah bekerjasama dengan program pemerintah dan masyarakat yang terlibat dalam pelaksanaan program tersebut. Wawancara dilakukan kepada Kepala Dinas Dukcapil DKI Jakarta, pegawai yang terlibat dalam program tersebut dan masyarakat terkait. Penemuan sumber data pada orang yang diwawancarai dilakukan secara purposive sampling yaitu dipilih dengan sengaja dengan pertimbangan dan tujuan tertentu.

\section{HASIL DAN DISKUSI}

Pelaksanaaan program SIDUKUN 3 in 1 yang di gagas oleh pemerintah DKI Jakarta lewat Dinas Kependudukan dan Catatan Sipil yang meraih Top 99 
inovasi pelayanan publik yang digagas oleh Kemenpan RB. Program tersebut lahir untuk menjawab keresahan dan permasalahan yang terjadi di masyarakat, khususnya dalam pelayanan administrasi kependudukan yaitu pengurusan akta kelahiran yang selama ini sangat lambat dan berbelit-belit dalam persyaratan yang ditentukan. Selain itu, keluhan masyarakat akan biaya pengurusan administrasi kepada pihak-pihak yang tidak bertangung jawab untuk melakukan maladministrasi dalam hal percepatan dalam pengurusan administrasi kependudukan yang tidak melalui prososes yang telah di tetapkan merupakan masalah yang harus diselaikan lewat program tersebut.

Lewat program yang SIDUKUN 3 in 1, Dinas Dukcapil pemerintah DKI Jakarta menawarkan pelayanan administrasi kependudukan dengan cepat tanpa dipungut biaya sedikitpun. Sehingga masyarakat tidak perlu lagi menunggu waktu lama untuk mendapatkan akta kelahiran. Selain itu, biaya persalinanan bagi ibu yang melahirkan di rumah sakit yang terdaftar sebagai warga DKI Jakarta akan ditanggung oleh pemerintah lewat BPJS di mana semua warga DKI mendapatkan akses tersebut tanpa membayar uang bulanan, karena sudah ditanggung oleh pemerintah, asalkan bersedia ditempatkan di kelas 3 .

Implementasi Program SIDUKUN 3 in 1 dari tahun ke tahun sangat berkembang pesat. Program tersebut lahir di tahun 2015 dan baru 6 rumah sakit yang terlibat dalam proses pelayanan publik tersebut dan pada tahun 2019 sudah 79 rumah sakit, 44 puskesmas dan 5.700. Akta kelahiran yang sudah dicetak oleh Dinas Dukcapil, alhasil program tersebut sukses dilaksanakan oleh pemerintah DKI Jakarta, terbukti dengan jumlah yang sangat signifikan mengalami kenaikan sangat tinggi dalam jumlah rumah sakit dan puskesmas yang terlibat cukup banyak. Hal tersebut disampaikan langsung Kepala Dinas Kependudukan dan Pencatatan sipil DKI Jakarta. Dalam implementasi kebijakan yang diukur dengan teori Grindle (1980: 7), dikemukan oleh Wibawa (1994,22), model Grindle ditentukan oleh isi kebijakan dan konteks implementasi. Ide dasaranya adalah bahwa setelah 
kebijakan ditransformasikan, barulah implementasi kebijakan dilakukan. Keberhasilannya ditentukan oleh derajat implementability dari kebijakan tersebut. Isi kebijakan tersebut mencangkup hal-hal berikut (Nugroho, 2011)

1) Kepentingan yang terpengaruhi oleh kebijakan dalam program SIDUKUN 3 in 1 yang digagas oleh pemerintah daerah, melakukan suatu terobosan dalam melahirkaan sebuah inovasi sesuai dengan Peraturan Pemerintah Nomor 38 Tahun 2017 mengenai inovasi pemerintah diselenggarakan pada prinsip, peningkatan efesiensi, perbaikan efektivitas, perbaikan kualitas pelayanan, tidak menimbulkan konflik kepentingan, beriorentasi kepada kepentingan umum, dilakukan secara terbuka, memenuhi nilai kepatutan dan dapat dipertangungjawabkan hasilnya tidak untuk kepentingan diri sendiri, dalam regulasi jelas disebutkan dalam membuat suatu terobosan dalam melahirkan program untuk melayani kelompok masyarakat bukan hanya sekedar wacana dalam berinovasi, akan tetapi diperlukan implementasi program. Dimana masyarakat harus menikmati dan merasakan pelayanan tersebut sehingga kebijakan yang dilahirkan pemerintah bisa dirasakan oleh kelompok sasaran yaitu masyarakat yang ingin mengurus administrasi kependudukan seperti akta kelahiran yang bisa langsung dimiliki tanpa persyaratan yang kaku dan berbelit-belit.

2) Jenis manfaat yang akan dihasilkan pada program SIDUKUN 3 In 1 yang dapat di nikmati oleh masyarakat harus juga dapat diamati, dari segi bagaimana ia bekerja dan menghasilkan sesuatu yang baik, kemudahan dalam pelaksananaan program tersebut masyarakat hanya menyiapkan menyiapkan Dokumen yang harus dilengkapi yaitu setiap bayi yang baru lahir harus memiliki nama untuk didata oleh pemerintah, kartu keluarga asli, KTP orang tua, membawa buku nikah dan ID BPJS Kesehatan orang tua, ketika semua terpenuhi masyarakat mendapatkan akta kelahiran dengan cepat.

3) Derajat perubahan yang diinginkan implementasi program tersebut harus mempunyai keunggulan dan nilai lebih dibandingkan dengan kebijakan 
sebelumnya di mana proses masih manual dan kaku, belum terlaksananya sistem intergrasi antara satu instansi dengan instansi lainya. Selalu ada sebuah nilai kebaruan yang melekat dalam sebuah program baru yang dihadirkan sehingga menjadi ciri yang membedakannya dengan yang lain, dalam hal ini program SIDUKUN 3 in 1 mempunyai kebaharuan dalam yaitu terintegrasinya 3 instansi berbeda dalam satu pelayanan yang sama yaitu penerbitan akta kelahiran dengan cepat dan biaya persalinan untuk melahirkan semua ditanggung pemerintah lewat ID BPJS kesehatan yang sudah terdaftar di rumah sakit yang ada di DKI Jakarta .

4) Kedudukan pembuat kebijakan SIDUKUN 3 in 1 ini hanya bisa diterima apabila telah teruji dan terbukti mempunyai keuntungan atau nilai lebih dibandingkan inovasi yang lama, program tersebut memberikan dampak yang positif dalam mempercepat pelayanan dan mempermudah masyarakat khususnya bagi ibu yang melahirkan dalam mengurusi administrasi kependudukan rumah sakit, semua biaya persalinan sampai keluar biaya di tanggung oleh pemerintah DKI Jakarta dan langsung mendapatkan akta kelahiran sebelum keluar rumah sakit, sehingga tidak perlu lagi mengurus administrasi kesana kemari untuk mendapatkanya, semua sudah dijadikan dalam satu loket pelayanan yang dikerjakan langsung oleh pihat rumah sakit dan pemerintah, sehingga masyarakat akan langsung menerima akta kelahiran yang sudah di buat.

5) Pemerintah DKI Jakarta sangat bertangung jawab terhadap pelaksana setiap program yang dibuat oleh instansi pemerintah, dalam program SIDUKUN 3 IN 1 Dinas Kependudukan dan Catatan Sipil yang mempunyai peran penting dalam menyukseskan pelaksanaan program tersebut, sehingga penghargaan yang didapat oleh pemerintah tidak hanya sebuah wacana, melainkan implemntasi program harus berjalan sesuai dengan persyaratan yang sudah di buat untuk masyarakat bisa menikmati pelayanan tersebut, selain piham pemerintah, pihak BPJS juga berperan penting dalam mendata masyarakat yang mempunyai Kartu Tanda 
Penduduk DKI Jakarta, sehingga semua pelayanan di rumah sakit bisa diproses oleh pemerintah untuk menangung semua biaya ketika masyarakat melahirkan di rumah sakit atau puskesmas yang mempunyai ruang persalinan. Ketika persyaratan terpenuhi pihak rumah sakit akan menginput semua data yang sudah dilengakapi untuk diintegrasikan ke Dinas Dukcapil atau di kenal dengan Goverment to Government (G2G) guna untuk mengeluarkan akta kelahiran bayi.

6) Sumber daya yang di gunakan dalam menyukseskan program tersebut sangat memadai, SDM yang digunakan sudah diseleksi dengan baik, dan diberikan pelatihan dalam mengunakan sebuah aplikasi atau pelayanan yang berbasi E-Governmnet sehingga ketika dokumen yang sudah lengkap bisa langsung dikirim melalui web layanan SIDUKUN 3 in 1 yang hanya dapat di akses oleh pihak Dinas Dukcapil dan rumah sakit terkait security data dan akses layanan, di mana mengurusi dokumen masyarakat ketika sudah lengkap. Sehingga ketika implementasi program mempunyai tingkat kerumitan yang boleh jadi lebih tinggi dibandingkan dengan inovasi sebelumnya, bisa diatasi karena SDM yang bisa diandalakan dalam menyelesaikan permasalahan yang ada .

Sehingga untuk mendapatkan pelayanan tersebut masyarakat harus menyiapkan Dokumen yang harus dilengkapi yaitu setiap bayi yang baru lahir harus memiliki nama untuk didata oleh pemerintah, kartu keluarga asli, KTP orang tua, membawa buku nikah dan ID BPJS Kesehatan orang tua. Dalam hal ini masih ada beberapa kendala khususnya masyarakat yang belum menyiapkan nama untuk anak atau bayinya pada saat lahir sehingga belum bisa diproses untuk mendapatkan akta kelahiran dan lainya dengan cepat. Hal ini terjadi karena masyarakat masih terbawa culture ketikan nama akan diberikan pada saat sudah menjalankan hajatan baru diberikan sebuah nama, sehingga mereka tidak bisa langsung diproses datanya dengan cepat untuk mendapatkan, Kartu Keluarga baru, akta kelahiran, Kartu Indentitas Anak (KIA) dan ID BPJS Kesehatan 
Program SIDUKUN 3 in 1 bisa dinikmati oleh semua masyarakat DKI Jakarta di berbagai rumah sakit umum kabupaten/kota, rumah sakit swasta dan puskesmas setiap kecamatan yang mempunyai tempat bersalin dan sudah terdaftar dalam proram SIDUKUN 3 in 1 yaitu RSUD Tarakan, RSUD Koja, RSUD Cengkareng, RSUD Pasar Minggu, RSUD Pasar Reo, RSUD Budhi Asih dan RSUD Kepulauan Seribu. Sedangkan Rumah sakit swasta, RS TK II Moh Ridwan Meuraksa, RSIA Budi Kemulian, RSKMC, RS Pelni, RS Yadika, klinik Fakhira AlBarkah, Klinik Fakhira Jagakarsa, Klinik Fakhira Sawah kunto, Klinik Fakhira Kebon Baru dan masih banyak lagi rumah sakit yang sudah terintergrasi dengan program tersebut yang belum dicantumkan namanya di atas, dikarenakan setiap harinya pemerintah terus melakukan sosialisasi kepada pihak rumah sakit yang belum bergabung dan masyarakat yang belum mengetahu program tersebut.

\section{KESIMPULAN}

Implementasi pelayanan publik dalam meningkatkan pelayanan administrasi kependudukan bukanlah sesuatu yang sulit dilakukan pemerintah DKI Jakarta, lewat program SIDUKUN 3 in 1 yang dimiliki Dinas Kependudukan dan Pencatatan Sipil DKI Jakarta, dalam mengatasi masalah yang terjadi khsusunya dalam pelayanan administarsi kependudukan yang sebelumnya sangat meresahkan masyarakat DKI Jakarta ketika ingin membuat akta kelahiran bayi dan melakukan pelayanan kesehatan pada saat di rumah sakit. Banyaknya masyarakat takut akan melahirkan di rumah sakit dikarenakan biaya yang terlalu mahal dan pengurusan administrasi yang terlalu terbelit-belit sehingga memerlukan waktu yang lama.

Hal tersebut telah dijawab oleh pemerintah DKI Jakarta dengan berjalannya program SIDUKUN 3 in 1, masyarakat DKI Jakarata yang telah terdaftar kependudukan oleh Dinas Dukcapil yang merupakan warga asli DKI Jakarta ketika melahirkan di rumah sakit/puskesmas terdekat, akan ditanggung oleh pemerintah DKI Jakarta dari awal melahirkan sampai keluar 
dari rumah sakit. Sehingga, pemerintah DKI Jakarta cukup berhasil melaksanakan pelayanan administrasi kependudukan, akan tetapi masih kurang dalam mesosialisasikan program tersebut sehingga masih banyak masyarakat yang belum mengetahuinya program "SIDUKUN 3 in 1" dalam memberikan layanan bagi anak yang dilahirkan di rumah sakit, langsung mendapatkan Surat Keterangan Kelahiran dari rumah sakit, Nomor Induk Kependudukan (NIK) bayi, Kartu keluarga yang sudah update, akta kelahiran, Kartu Identitas Anak serta BPJS Kesehatan untuk bayi dengan cepat tanpa pengurusan yang lambat atau dipersulit dan semua pelayanan tersebut tidak dipungut biaya yang tanggung oleh pemerintah DKI Jakarta. Pada tahun 2019 sudah 79 rumah sakit, 44 puskesmas dan 5.700 akta kelahiran yang sudah dicetak oleh Dinas Dukcapil, alhasil program tersebut sukses dilaksanakan oleh pemerintah DKI Jakarta terbukti dengan jumlah yang sangat signifikan mengalami kenaikan dalam jumlah rumah sakit dan puskesmas yang terlibat.

\section{REFRENSI}

Anonimus. LAN-RI. !999. Pedoman Penyusunan Laporan Akuntabilitas Kinerja Instansi Pemerintah. Jakarta : LAN-RI.

Creswell, J. W. (2009). Research Design: Qualitative, Quantitative, and Mixed Method Approaches. California: SAGE Publication

Governance in Practice: Belajar dari Pengalaman di Indonesia. Yogyakarta: Dies FisipolUGM ke 49.

Grindle, merille S., (ed.), 1980, Politics and Policy Implementation in the Third Word, New jersey: Princentown University Press.

Moleong, J. L. (2007). Metodelogi Penelitian Kualitatif. Bandung: PT. Remaja Rosdakarya

Mukarom,Wijaya laksana,2016. Manajemen Pelayanan Publik.Bandung.CV Pustaka Setia

Muluk, K. (2008). Knowledge Management: Kunci Sukses Inovasi Pemerintahan Daerah.Malang: Bayu Media.

Nugroho, Riant, 2009. Public Policy. Jakarta , Gramedia. 
IMPLEMENTASI PELAYANAN PUBLIK PADA PROGRAM SIDUKUN 3 IN 1 DALAM PENGURUSAN ADMINISTRASI KEPENDUDUKAN DI DKI JAKARTA

Osborne, S. P. (2005). Managing Change and Inovation in Public Service Organizations. New

Purwanto Erwan Agus, 2009. Strategi Penerapan Standar Pelayanan Untuk Reformasi Birokrasi,Gaya Media, Yogyakarta.

Rukayat, Y. (2017). Kualitas Pelayanan Publik Bidang Administrasi Kependudukan diKecamatan Pasir Jambu. Jurnal Ilmiah Magister Ilmu Adminitrasi Vol 11, No. 2.

Setiyono, B. (2016). Birokrasi dalam Perspektif Politik Administrasi. Bandung : NuansaCendekia.

Suaedi, d. W. (2010). Revitalisasi Administrasi Negara Reformasi Birokrasi dan E-Government. Yogyakarta: Graha Ilmu.

Widayahseno, B. (2015). Inovasi Bupati di ruang demokrasi membangun kesadaran InovasiBirokrasi. Jurnal Ilmu Sosial dan Politik.

Routledge.Pratikno. (2004). Dari Good Governance Menuju Just and Democratic Governance. 